\title{
IMPROVEMENT OF SELECTED LOGISTICS PROCESSES USING QUALITY ENGINEERING TOOLS
}

\author{
Michat ZASADZIEŃ \\ Silesian University of Technology \\ Jozef ŽARNOVSKÝ \\ Slovak University of Agriculture in Nitra
}

\begin{abstract}
:
Increase in the number of orders, the increasing quality requirements and the speed of order preparation require implementation of new solutions and improvement of logistics processes. Any disruption that occurs during execution of an order often leads to customer dissatisfaction, as well as loss of his/her confidence. The article presents a case study of the use of quality engineering methods and tools to improve the e-commerce logistic process. This made it possible to identify and prioritize key issues, identify their causes, and formulate improvement and prevention measures.
\end{abstract}

Key words: logistics, warehouse, e-commerce, quality, 5 Why, FMEA, improvement

\section{INTRODUCTION}

Logistics processes are one of the most significant processes in an enterprise. Modern business environment requires from suppliers efficient and defect - free flow of materials and information. Therefore, well - executed logistics processes should integrate flows of material and information streams, and their essence is to coordinate these flows with other processes [10]. S. Krawczyk [9] defines a logistics process as a process that is related to other processes, while taking into account the following aspects: place, time, cost, efficiency. Typical logistics processes can be divided into primary and supporting processes, as shown in Table 1.

Primary processes are those that combine the processes of supply, production and distribution - they transform the temporal, spatial, quantitative and qualitative properties of goods and information, i.e. warehouse operations, transhipment transport operations, and material management. On the other hand, supporting logistical processes include planning and decision making to shape, coordinate and optimize logistics systems [5, 12].

Improvement of logistics processes should be one of the core areas of the company's business focussed on improvement. Improvement should be oriented to one or more areas that can be identified as the following criteria: economic (e.g. reduction of logistical costs), technical (e.g. shortening of material storage time), organizational (e.g. improvement of information flow), social (e.g. improvement of customer service) and ecological (e.g. waste reduction) [4].

Table 1

Logistics processes

\begin{tabular}{lll}
\hline \multicolumn{1}{c}{$\begin{array}{c}\text { Processes of material } \\
\text { and goods flow }\end{array}$} & \multicolumn{1}{c}{ Primary processes } & \multicolumn{1}{c}{ Supporting processes } \\
Storage & Planning of supplies, production, stocks & Logistics management \\
Transport & Giving instructions for shipment, exection of order & Controlling of logistics \\
Acceptance of goods & Product flow control & Research and development of logistics \\
Shipping of goods & Preparation of customer orders & Comprehensive coordination \\
Waste management & Planning of shipments, service and logistic support & Waste management \\
Service, logistic support & & Service and logistic support management \\
\hline
\end{tabular}

Source: [2]. 
Improvement of a logistics process can be accomplished according to the following scheme:

1. Identification and prioritization of problems.

2. Selection of problems that will be most beneficial for the process improvement and capabilities (resources) of the organization.

3. Finding the root causes of the problem and where they occur in the process.

4. Development and implementation of improvement activities that will reduce or eliminate the problem.

5. Development and implementation of preventive actions to prevent future problems.

6. Implementation of control measures to check effectiveness of the changes.

7. Possible corrections of activities as a result of undertaken control activities [18].

Among the range of tools and methods used to improve processes, we can distinguish those that help identify problems, find the causes and sources of abnormalities, and those to help to develop and implement improvement and prevention efforts. The first group includes popular tools such as the Pareto (ABC) diagram, the control chart, the Ishikawa diagram $(5 \mathrm{M}), 5$ Why, the relationship diagram, etc. $[1,8,11,15]$. The tools supporting the improvement and prevention efforts are first of all: FMEA, $8 \mathrm{D}$, and DMAIC $[11,13,14]$.

\section{THE ANALYSED PROCESS}

The selected warehouse mainly distributes sports articles and is responsible for supplying twenty - eight commercial units, i.e. large - format sports stores, as well as it manages e-commerce. There are number of logistics processes in the selected warehouse, consisting of: reception, storage, picking, releasing and shipping. Material flow is realized using internal transport and the flow of information is supported by the WMS (Warehouse Management System).

The shipment process in the e-commerce department will be subject to an analysis, which is a key task for the warehouse. It consists of several stages, which are presented in the following diagram (Figure 1).

The shipment process includes the following elements:

1. Order sending to the system.

2. Printing orders in departments - after orders are sent they are printed in the departments of the warehouse.

3. Picking items for orders. This process is extremely important for the proper functioning of e-commerce. Most orders consist of articles from different brands,

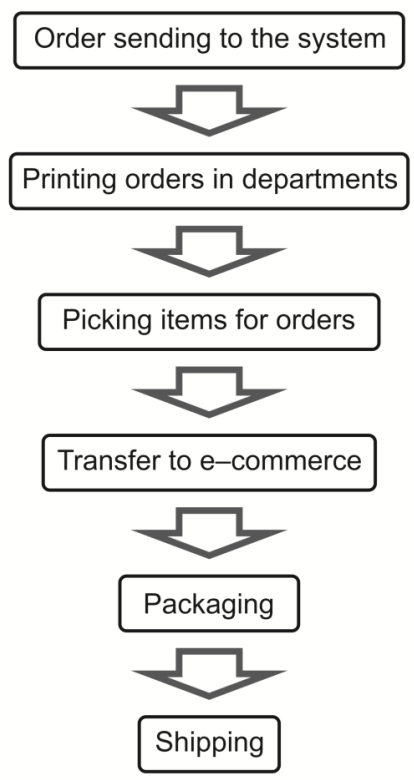

Fig. 1 Diagram of shipment process in the e-commerce department

Source: [3].

which means that the order is completed by different, independent departments. In case one of the departments has delay the entire order is incomplete and therefore the order cannot be completed on time.

4. Transfer to e-commerce - this involves delivering complete articles to the e-commerce department,

5. Packaging - the process of adequate packing the order as quickly as possible.

6. Shipping - is the process that takes place after the order is sorted. Packages and necessary information are sent.

The main measure of the process is the shipment time of the order to the customer, which is $D+1$ (which means that the shipment will take place on the next day from the moment the customer placed the order).

\section{IDENTIFICATION OF PROBLEMS}

During the study, an interruption measurement sheet was introduced in the e-commerce department to identify inconsistencies that interfere with the shipping process. Figure 2 shows an example sheet.

All interruptions identified by the measuring sheets are listed in Table 2.

\begin{tabular}{|c|c|c|}
\hline \multicolumn{3}{|c|}{ INTERRUPTION MEASUREMENT SHEET } \\
\hline \multicolumn{3}{|c|}{$\begin{array}{l}\text { Department: e-commerce } \\
\text { Date: } 02.04 .2017 \\
\text { Shift: } 1^{\text {st }} \\
\text { Leader: Jan Kowalski }\end{array}$} \\
\hline \multicolumn{3}{|c|}{ IDENTIFIED INTERRUPTIONS } \\
\hline Interruption & Subprocess: & Temporary remedial action: \\
\hline 1. Delayed picking & Compilation & Phone to the shift supervisor \\
\hline 2. & & \\
\hline 3. & & \\
\hline
\end{tabular}

Fig. 2 Interruption measurement sheet 
Identified interruptions and problems in the shipping process

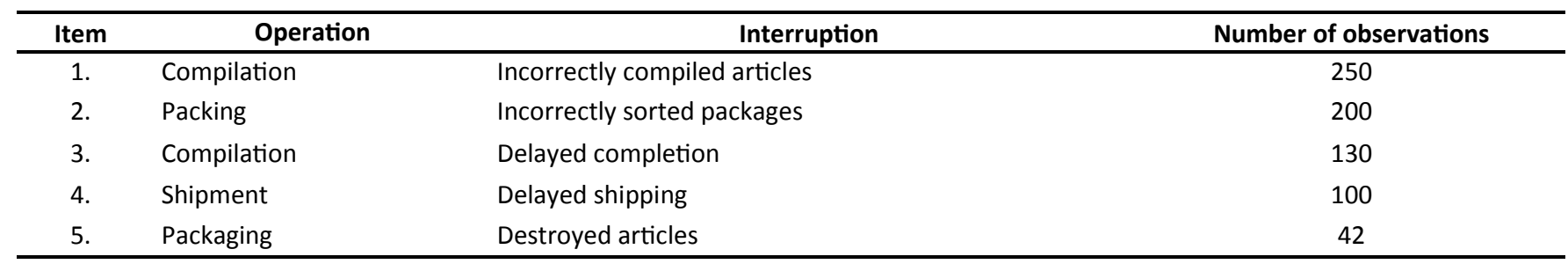

The most common interruptions in the e-commerce department that affect the quality of the shipment process are: incorrectly compiled articles (250 incidents) and incorrectly sorted parcels (200 cases). An operation in the process that generates the most incompatibilities is compilation (380 incidents - over $50 \%$ of all reported inconsistencies). Consequently, this element of the process has been selected for improvement.

\section{CAUSES OF PROBLEMS}

The next stage of the analysis is to diagnose the cause of the above disturbances i.e. incorrectly completed orders and late completion of orders. For diagnosis the 5 Why tool was used, which aims to identify the root cause of the problem. The results of the analysis are shown in the figures below (Figures 3 and 4).

The first to analyse were wrongly picked articles. This is most commonly occurring problem (250 times during the quarter). Thanks to the 5 Why tool, two main causes of problems have been identified: frequent failures of bar code scanners and unwieldy carts for order picking.

Delayed completion of orders occurred during the period considered 130 times. The main causes of these incidents were: permanent problems with the efficiency of the scanning system and the lack of experience of people performing the picking.

\section{IMPROVEMENT MEASURES}

The FMEA method was used to evaluate the identified disturbances during the shipment process, which allows for the verification of interfering factors and proposed improvement measures. The evaluation was done with three scales:

$-Z$ - significance of the effect of defect,

- R-probability of defect occurrence,

- W-defect detection.

Each scale is assigned a rating scale of 1 to 10 , while the product of these values shows us the level of probability of risk (RPN) that is associated with the occurrence of a particular disturbance [7]. Scale estimation was based on: prepared interruption measurement sheet, opinion of experienced employees at all levels of the company and the results of conducted internal audits. The results are shown in Table 3.

The FMEA analysis shows that the most likely risk of disruption to shipment was reported in the case of too fast introduction of new employees (RPN $=245)$ and unwieldy pickup carts (RPN $=72$ ).

At a later stage of analysis, improvements and preventive actions were proposed and implemented, and their usefulness was also determined using the RPN indicator, as shown in Table 4.

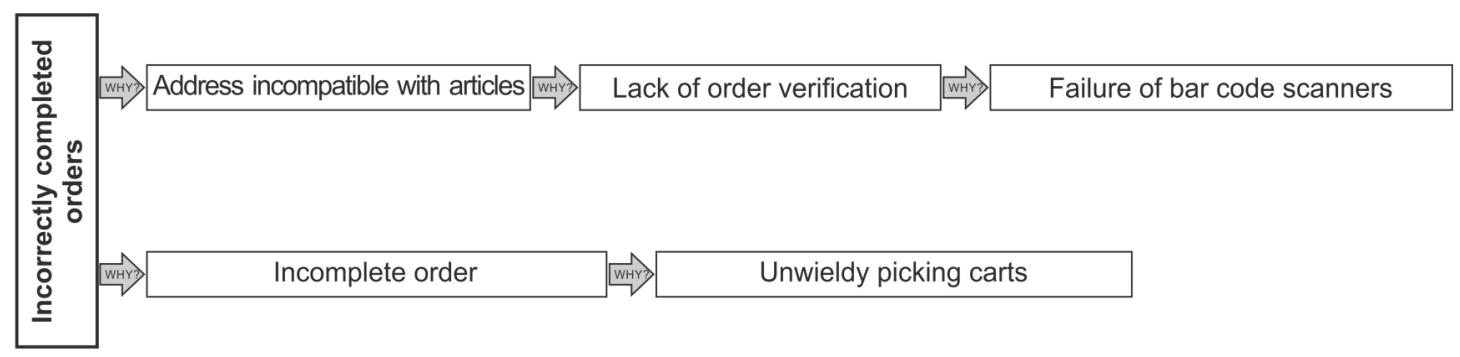

Fig. 3 The 5 Why analysis - incorrectly completed orders

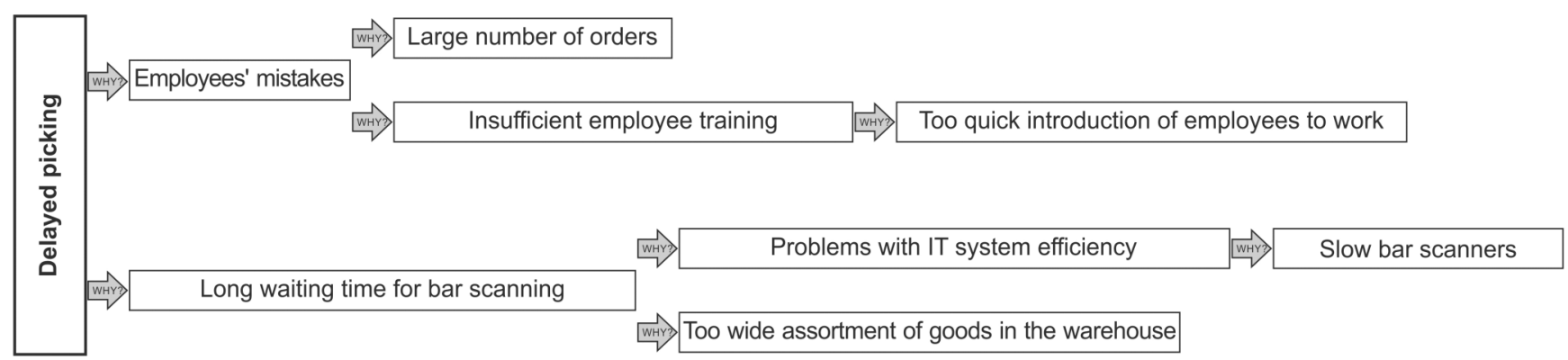


Table 3

The FMEA analysis of the shipping process

\begin{tabular}{|c|c|c|c|c|c|c|}
\hline Potential problem & Potential effects & Potential causes & $\mathbf{Z}$ & $\mathbf{R}$ & w & RPN \\
\hline \multirow{2}{*}{ Incorrect completion of order } & \multirow{2}{*}{ delayed delivery time } & scanner failure & 9 & 6 & 1 & 54 \\
\hline & & unwieldy carts & 9 & 4 & 2 & 72 \\
\hline \multirow{2}{*}{ Delayed completion of order } & \multirow{2}{*}{$\begin{array}{l}\text { delivery not compliant } \\
\text { with the order }\end{array}$} & too fast introduction of new employees & 7 & 7 & 5 & 245 \\
\hline & & slow code scanners & 7 & 3 & 3 & 63 \\
\hline
\end{tabular}

Table 4

The FMEA analysis after improvement measures

\begin{tabular}{|c|c|c|c|c|c|c|c|}
\hline Potential causes & $\begin{array}{c}\text { RPN } \\
\text { before }\end{array}$ & Improvement measures & Preventive actions & $\mathbf{Z}$ & $\mathbf{R}$ & $\mathbf{w}$ & $\begin{array}{l}\text { RPN } \\
\text { after }\end{array}$ \\
\hline scanner failure & 54 & $\begin{array}{c}\text { Change of data collection } \\
\text { technique }\end{array}$ & weekly work meetings & 9 & 3 & 1 & 27 \\
\hline unwieldy carts & 72 & Replacement of carts & - & 9 & 2 & 1 & 18 \\
\hline \multirow{2}{*}{$\begin{array}{l}\text { too fast introduction of } \\
\text { new employees }\end{array}$} & 245 & Additional trainings & Training records & 7 & 5 & 4 & 140 \\
\hline & 245 & trial period & Independent work permit & 7 & 4 & 2 & 56 \\
\hline \multirow{2}{*}{ slow code scanners } & 63 & $\begin{array}{c}\text { Technical abnormality } \\
\text { sheet }\end{array}$ & weekly work meetings & 7 & 2 & 2 & 28 \\
\hline & 63 & $\begin{array}{c}\text { Change of data collection } \\
\text { technique }\end{array}$ & weekly work meetings & 7 & 1 & 1 & 7 \\
\hline
\end{tabular}

The following solutions were chosen for implementation:

1. Changing the data collection technique, which will reduce the PRN for two causes: scanner failures and scan system slowdown.

2. Replacement of carts for the cause - unwieldy carts.

3. Introduction of trial period for new employees.

Change of data collection technique

The new technique that can be used to replace bar codes is RFID (Radio-frequency identification) [6]. In order to implement this solution in practice it is necessary to equip a warehouse with IT infrastructure based on Wi-Fi. Each workstation should be equipped with a computer (tablet) for data transfer and collection, a data reader and a printer. During manual scanning, which is currently practiced in the warehouse, the picker is able to complete about 350 orders, while the new technique it is about 1000 orders.

\section{Replacement of carts}

So far used carts were fitted with reusable trays of standard size (1 large or 2 small), which caused the small items to "be missed" while emptying the tray. The "Pick\&Pack" carts consist of shipping cartons, and picking consists of stacking articles into suitable cartons. These cartons immediately serve to pack ready - made orders, so after the completion the carton is closed with the ordered articles, labelled and sent immediately to shipping. This process saves time and costs. The only cost to be incurred by the warehouse will be the purchase of new multifunctional carts, which are shown in Figure 5.

\section{Training of new employees}

In case of employing new or seasonal workers, the scope of training has been extended. In addition to the theoretical and practical classes in the first period of work, any newly - employed worker will have a "tutor" implementing him/her into the process.
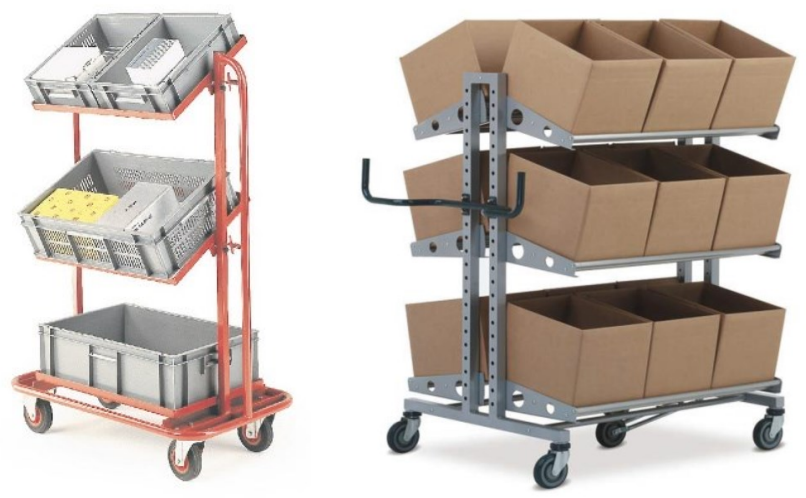

Fig. 5 Comparison of classic and „Pick \& Pack” cart Source: $[16,17]$.

\section{SUMMARY}

Analysis of the non - compliance of the shipment process using tools such as interruption sheets, 5 Why and the FMEA method has illustrated that the shipping process in the e-commerce department of the selected warehouse is complex, and the interferences that are associated with its correct course are interrelated. During the analysis, the following disruptions to the shipment process were identified: delayed completion of orders, delayed shipment, destroyed articles, incorrectly sorted parcels and erroneously picked articles. Analysis with the 5 Why tool has helped to identify the causes that are responsible for the disruption during the shipping process. The most important are: faulty scanners, inoperative carts, slow running scanners, under - trained pickers.

Thanks to the above results, the FMEA analysis has been performed, which has identified the reasons for the highest probability of risk (RPN) interruptions, namely: unwieldy carts, too fast introduction of new employees, lack of cooperation with the IT department. 
The result of the actions was defining of improvement and preventive actions, i.e.:

- replacement of the bar code system with RFID technology,

- introduction of the „Pick\&Pack” carts,

- change of training system of new employees.

Because of its low effectiveness, no additional training was decided.

Thanks to the use of tools and methods of quality engineering in the logistics process, it was possible to improve it, and the solutions proposed by the analysis helped to solve the most significant problems.

This article was prepared within the statutory research titled "Methods and tools for improving products and services on the selected examples" work symbol 13/030/BK_17/0027 performed at Silesia University of Technology, Institute of Production Engineering.

\section{REFERENCES}

[1] Z. Andrássyová, J. Žarnovský, Š. Álló, J. Hrubec. "Seven new quality management tools". Advanced Materials Research, vol. 801, 2013.

[2] P. Blaik. Logistyka. Koncepcja zintegrowanego zarzqdzania. Warszawa: PWE, 2010.

[3] K. Cetera. „Doskonalenie procesów logistycznych w wybranym magazynie przy zastosowaniu metod zarządzania jakością". M.A. thesis, Silesian University of Technology, Poland, 2017.

[4] L. Dwiliński. Zarys logistyki przedsiębiorstwa. Warszawa: Oficyna Wydawnicza Politechniki Warszawskiej, 2006.

[5] K. Ficoń. Procesy logistyczne w przedsiębiorstwie. Gdynia: Impuls Plus Colsulting, 2001.

[6] K. Finkenzeller. RFID Handbook: Fundamentals and Applications in Contactless Smart Cards, Radio Frequency Identification and Near - Field Communication. John Wiley \& Sons, 2010.
[7] B. Gajdzik, J. Sitko. "Steel mill products analysis using qualities methods". Metalurgija, vol. 55, iss. 4, pp. 807 -810, 2016.

[8] M. Sokovic, D. Pavletic, K. Kern Pipan. "Quality Improvement Methodologies - PDCA Cycle, RADAR Matrix, DMAIC and DFSS". Journal of Achievements in Materials and Manufacturing Engineering, vol 43, issue 1, pp. 476-483, 2010.

[9] K. Ishikawa. Guide to Quality Control. Tokio: Asian Productivity Organization, 1986.

[10] S. Krawczyk. Logistyka w zarzqdzaniu przedsiębiorstwem. Wrocław: Wydawnictwo AE, 2000.

[11] J. Łuczak, E. Maćkiewicz. „8D oraz inne metody zarządzania jakością w branży motoryzacyjnej (OE-OES) analiza przypadku". Problemy Jakości, no 11, pp. 3543, 2016.

[12] K. Midor. "An analysis of the causes of product defects using quality management tools". Management Systems in Production Engineering, no. 4, pp. 162-167, 2014.

[13] F. Mroczko. „Logistyka”. Prace Naukowe Wyższej Szkoty Zarzq̨dzania i Przedsiębiorczości, seria: Zarzq̨dzanie, no 46, 2016.

[14] B. Skotnicka-Zasadzień. "Selected aspects of quality engineering in managing the operation of machinery and equipment mining - case study". Systemy Wspomagania w Inżynierii Produkcji, z. 4, pp. 198-208, 2016.

[15] N.R. Tague. The Quality Toolbox, Milwaukee: ASQ Quality Press, 2005.

[16] www.hall-fast.com

[17] www.wanzl.com

[18] M. Zasadzień. "Selected methods and tools for analysing product nonconformity in the automotive industry". Systemy Wspomagania w Inżynierii Produkcji, z. 1, pp. 150-160, 2015.

\author{
dr inż. Michał Zasadzień \\ Silesian University of Technology \\ Faculty of Organization and Management \\ Institute of Production Engineering \\ ul. Roosevelta 26, 41-800 Zabrze, POLAND \\ e-mail: michal.zasadzien@polsl.pl \\ Doc. Ing. Jozef Žarnovský, PhD. \\ Slovak University of Agriculture in Nitra \\ Department of Quality and Engineering Technologies \\ Tr. A. Hlinku 2, 94976 Nitra, SLOVAKIA \\ tel.: +421376414308, \\ e-mail: Jozef.Zarnovsky@uniag.sk
}

